Tomasz Mizerkiewicz

Adam Mickiewicz University in Poznań

tommizer@amu.edu.pl

ORCID: 0000-0002-4419-5423
Data przesłania tekstu do redakcji: 05.02.2019

Data przyjęcia tekstu do druku: 10.02.2019

\title{
Art After Democracy, Art Before Democracy
}

Abstract: Mizerkiewicz Tomasz, Art After Democracy, Art Before Democracy. "Poznańskie Studia Slawistyczne" 17. Poznań 2019. Publishing House of the Poznań Society for the Advancement of the Arts and Sciences, Adam Mickiewicz Univesity, pp. 15-21. ISSN 2084-3011.

The paper describes today's new situation of art facing antidemocratic processes. The powerful metaphor of Parthenon of books is used, which once was the name of an installation by Marta Minujín presented just after the fall of Argentinian brutal regime in the early eighties and reinstalled again few years ago. The author points that popular "posts" of humanities (postmodernism, postsecularism etc.) need to be replaced by the philosophy of art being after some definite change. The new temporal and public condition of art being after is the result of its dramatic contemporary and future challenges.

KEYWORDS: democracy; art; book-art; postmodernism

After the fall of the military junta in Argentina in 1983, the artist Marta Minujín created an installation to welcome in democracy. She placed 20,000 books banned by the generals who had led the brutal regime, and arranged them on a metal scaffolding in the shape of the Greek Parthenon. The list of banned titles was predictable, but also reflected the personal idiosyncrasies of the Argentine dictators. Among the various forbidden books were the works of Freud, Sartre, Foucault and Hemingway, and even Antoine de Saint-Exupéry's The Little Prince. For years the famous "Parthenon of Books" was one of the strongest visual representations of the belief that democracy begins with freedom of speech and artistic expression. Drawing attention to this was the work's ephemeral form, which combined ancient art with literary and, more generally, book culture, as well as with modern conceptual art. Minujín's installation depicted the state of art just before democracy, before it crossed the threshold of the democratic reality symbolized by the Parthenon. This show, held on one of the main boulevards of Buenos Aires, turned into a spectacular social holiday, and 
a few days later, the works placed on the scaffolding were handed out to the crowd of spectators. Minujín's invention therefore also included the creation of new audiences, new rules for the circulation of artistic works, and new ways of displaying them; all of this together helped to create the moment of a "re-entry into democracy", with art taking part in fulfilling the people's will for democracy to be reinstated.

In 2017 at the Documenta 14 exhibition in Kassel, the Argentinean artist was asked to recreate her Parthenon of books. This time the installation was erected on the square where in 1933 German Nazis burnt 2,000 books that had been written by Jewish authors or were otherwise deemed to be foreign to the German spirit, such as the works of Karol Marx. This second Parthenon of books included works forbidden in the past, but also others outlawed in many parts of the world today. The significance of this second installation by Marta Minujín certainly cannot be reduced to a form of postmodernist quotation (still quite common today), that is, an ironic repetition reflecting a conviction that the serious content which initially permeated her work is no longer valid in a world where historical contradictions have been resolved, i.e. the world after Francis Fukuyama's "end of history". Nor is the meaning assigned to this repeated installation lessened by the belief that Europe remains able to effectively stave off or at least control the terrible spectres of its past; meanwhile, while from within the Crystal Palace, to use Peter Sloterdijk's well-known metaphor, it judgmentally admonishes societies living outside such a blissful state of security, maintaining that they still have a lot of "catching up" to do due to the censorship of art in their countries. The act of re-creating the Parthenon of books seems also to be an expression of the very disturbing stage at which contemporary art finds itself now in Europe as well, and it is certainly no accident that the idea of returning to a work that is iconic of a democratic Argentina was co-authored by Adam Szymczyk, the Polish curator of Documenta 14. This repetition seems to be a visual representation of a place and image that some societies have begun putting behind them, entering into the puzzling world after democracy. The period from 1983 to 2017 can be seen as the time when Europe and its arts, Central and Eastern Europe as well, having fully crossed the threshold of democracy, now once again unexpectedly made an exit, entering into a post-democractic reality. Today, it is no longer so difficult to imagine a new list of forbidden books, one 
that would include the works of Orhan Pamuk, texts by the group Pussy Riot published in book form, writings by George Soros, some of the Olga Tokarczuk's novels, or J.K. Rowling's Harry Potter series. In any event, the Parthenon of books is one of those ideas that we are sometimes forced to abandon with great regret when we set off on a reluctant journey with no known purpose, and the exhibition in Kassel thus appears to have unknowingly acted as a farewell to an understanding of the relationship between art and democracy that had sufficed until recently.

It is therefore necessary to supplement the means by which we currently analyse the relationship between art and democracy, a situation that is more worrying than that expressed in Derrida's notion of the "democracy to come". Most ideas akin to Derrida's high-minded thinking basically describe a social world for which democracy remains a foundational paradigm. In 2010, Polish art historian Piotr Piotrowski described in his monograph Agorafilia the history of democracy and artistic engagement in public affairs in post-communist Europe, concluding his description with a chapter on "unfulfilled democracy". At the time, it was undisputed that democratic principles represented an unchallengeable court before which artistic matters should be held accountable; within Piotrowski's diagnosis of unfulfilled democracy was a concealed demand for the genuine fulfilment of democracy. Similarly, in the major collective work Doing Democracy, prepared by Nancy S. Love and Mark Mattern, the question posed by the authors boils down to how to "do" democracy more effectively, more honestly, and with renewed energy in a world where it is sufficient to merely improve it.

In other words, we are entering into a space and time in which we are after, and not post. The "good old days" when we were surrounded by postmodern culture, post-political society, and in our case, post-communist society, and the radio played post-rock music, seem now to be a thing of the past. By describing our cultural situation in terms of posts, we expressed the feeling that, for instance, the modern world still existed, but in the state of displacement, as sites of conflict were identified and addressed through efforts to make improvements using a variety of mechanisms available to us through the interval of time signalled by post. This kind of calm and efficient critical work is not possible in a situation when we are after. When we are after, we are in a reality that is meant to be an alternative to 
a democratic France, to a democratic Central Europe, and, of course, an alternative to a democratic Germany. When we are after, we find that the pacts that have been in place up until now have been broken, although it often looks like a hybrid break: a state continues for some time in which it is unclear whether or not someone has actually broken with democracy, though, a short time later, the presence of undemocratic principles on another peninsula becomes quite obvious. For all of these reasons, we cannot speak of post-democratic art, but rather of art after democracy. "Postdemocratic art" as a term probably does not even exist and would be nonsensical, because the entire post discourse has been situated within the framework of democratic principles. The term "art after democracy", on the other hand, quite precisely names this new situation and the operations taking place within it.

In order to describe in more detail the psycho-artistic dimension of contemporary creative activity, and the emotional and intellectual situation created by it, we need to start with the fact that for many artists the rapid divisions made in the realm of art by people in the arts themselves provided a very bitter lesson. It is not so difficult to find another Gérards Depardieus singing songs of praise in honour of the undemocratic worlds where they have decided to live. The "Depardieu Syndrome" is manifested in the activities of many directors of films with more or less open propaganda content, by cultural award committees, publishers and directors of cultural institutions, and by some poets, former literary critics and others. The illusion that there is an unbreakable bond between art and democracy is something that artists must now bid farewell, as this link is clearly a valuable historical rarity. The bitter taste of this is intensified by a further observation that the undemocratic actions of some artists are quite effective at generating audiences, using tricks that a pro-democratic artist might be ashamed to use, though his colleagues find a troubling effective agreement with the audience of a film showing only non-culpable sufferings from the recent past of the nation. What has been understood up until now as the circulation of art is beginning to occur in unexpected ways, and it is not, as a pro-democratic artist would note with regret, lacking in inventiveness, although this concerns in particular the infrastructure itself, because the artistic tricks used are already known to us. 
Moreover, the psycho-artistic state of mind associated with life after democracy reflects the sense of shock that something like this can even happen. The undemocratic manager of the new situation sometimes has an emotional and intellectual advantage, because it is suddenly he who sets and defines the rules of the artistic game. And it is he who speaks, albeit often in a hybrid manner, his cynical and obscene truth that democracy is no longer the issue. Let us try to get a good insight into what I call the psycho-artistic experience of this meeting. If he is honest, an artist knows that it is also his alter ego who is speaking. It is not difficult to recall that the common practice of combining artistic activities with business interests, monetising every creative success, commercialising and commodifying artistic gestures, led in the long run to the creation of structures in which contemporary art collaborated with everything that impinges on democratic principles today. Other artists, in turn, need to remember how easy it was over the years for them to formulate radical social and artistic programmes, the carelessness with which they attacked democratic institutions, and the zeal with which they praised Chantalous Mouffe and her idea of conflict as a necessary amendment to democracy. Artists in many ways moved into various undemocratic niches within the framework of a democracy taken for granted and treated as something inalienable.

The next psycho-artistic element is the experience of the loss of security and exposure to harm. It is no coincidence that the first meetings with undemocratic managers were based on lost court cases (the case of Pussy Riot) and the evictions of artists from the spaces and institutions they had thus far occupied. Art after democracy loses its security, becoming a place of danger, of intensified experience. Therefore, the result of this situation is very often a knee-jerk call for restitution of the artistic ethos, a spontaneous revival of solidarity within the artistic community, manifestations of which can be quite easily observed. The resulting new ethical moment means that an often quite unpredictably marked work or artist becomes the cause of an ethical reaction, a reflex action to defend the right of a work of art to exist and to speak without censorship. The resulting situation tests the moral value of the position taken, verifies the ability for courage to be shown, and examines the potential for various forms of heroism to emerge. Successive tests of this kind produce this ethos as a set of principles that 
are in effect during a time of lawlessness offending art, guiding it in its disciplined but blind wanderings in search of a new path towards democracy, according to a principle once described by Alain Badiou as a movement of anabasis. Authorities are being established anew, because in the initial moments after democracy it is quite clear that one can no longer look toward people like Slavoj Žižek, who supported the current resident of the White House in the last presidential elections.

Complementing this picture is the somewhat controversial thesis that art after democracy knows that it was not an effective means for supporting democracy when its rules were still in effect. Perhaps this was never even possible, but in any case, it lacked the strength, the inventiveness, and the far-reaching perspectives needed to prevent the emergence of an undemocratic reality. However, art in our part of Europe, in Central and Eastern Europe, has a very vivid memory of and confidence in its effectiveness during previous anti-democratic crises. Its legacy undoubtedly seems to be that it was able and clearly remains able to be useful in expressing the state of things after democracy, portraying all its key emotional and intellectual dimensions, and in this way, effectively do the work of mourning for this lost, precious object. The art archives of Central and Eastern Europe hold knowledge about different scenarios of transition from being after democracy to being before democracy. On this path, the art of our region has proven in retrospect to have had social importance, its messages listened to closely, effectively influencing the process of moving toward a democratic reality. Artistic activities after democracy, which are now just beginning, must therefore be understood as a very subjective, transitory move toward art before democracy. This leads to the creation of a new archive of knowledge about the importance of art for democracy, an archive containing works that are banned, or, due to a regime's oversights, not (yet) banned, works which give rise to a new mood of hope and the potential for joy at being able to once again stand at the threshold of democracy and cross it. From these works someone who knows how, where and when will construct new Parthenons of books, because the path of these Parthenons runs not only along the bleak trail from Buenos Aires to Kassel, but also leads back to the new Buenos Aires, and also to wherever a Parthenon of books is most hated, that is, most needed. 


\section{References}

Love, N.S., Mattern M. (eds) (2013). Doing Democracy. Activist Art and Cultural Politics. New York: Suny Press.

Piotrowski, P. (2010). Agorafilia - sztuka i demokracja w postkomunistycznej Europie. Poznań: Rebis.

Piotrowski, P. (2012). Art and Democracy in Post-Communist Europe. Chicago: University of Chicago Press. 